ORIGINAL ARTICLE / ARTIGO ORIGINAL

Analysis of vaccination status of preschool children in Teresina (PI), Brazil

\title{
Análise da situação vacinal de crianças pré-escolares em Teresina (PI)
}

\author{
Ana Catharina Nunes Fernandes', Keila Rejane Oliveira Gomes', \\ Telma Maria Evangelista de Araújo², Regilda Saraiva dos Reis Moreira-Araújo ${ }^{3}$
}

\begin{abstract}
Introduction: Immunization is a priority action of the Ministry of Health for contributing to reducing child mortality; however, studies show increased vaccination delays and non-vaccination. Objective: This study aims to analyze the immunization status of preschool children in Teresina - PI. Methods: Crosssectional study involving 542 children, aged 2-6 years, enrolled in local public schools in four Municipal Childhood Education Centers selected at random, following the proportional division by regions of the city. Data were collected through a pre-coded and pre-tested form, in addition to scanning the children's vaccination card. For univariate descriptive statistical analysis, Pearson's $\chi^{2}$ Test and Fisher's Exact Test were used, and for multivariate analysis, multiple logistic regression was conducted using SPSS version 17.0. The study complied with the ethical aspects in accordance with current legislation. Results: The frequency of delayed vaccination/non-vaccination was $24.9 \%$. The average of non-administered vaccines was 1.7 (SD \pm 1.2$)$ and of delayed vaccines was 3.3 (SD \pm 1.6 ). The binomial logistic regression model showed a significant association $(\mathrm{p}<0.05)$ between young caregivers (under 24 years) and low frequency in childcare consultations with delayed vaccination/non-vaccination. There was no association with the variables related to the experience of children in the vaccination room and with the implementation of the Family Health Strategy. Conclusion: Ensuring and strengthening primary healthcare actions are essential tools to reduce non-vaccination and vaccine delays. Professionals who care for children in vaccination rooms need to sensitize themselves to guide and encourage parents/caregivers to meet the vaccination schedules without delays or errors.
\end{abstract}

Keywords: Immunization. Immunization Coverage. Child Health. Nursing. Community Health Nursing. Epidemiology.

'Graduate Program in Health Sciences at the Universidade Federal do Piauí -Teresina (PI), Brazil.

${ }^{2}$ Graduate Program in Nursing at the Universidade Federal do Piauí -Teresina (PI), Brazil.

${ }^{3}$ Graduate Program in Food and Nutrition at the Universidade Federal do Piauí-Teresina (PI), Brazil

Corresponding author: Ana Catharina Nunes Fernandes. Conjunto União I, Quadra 2, Casa 3, Memorare. CEP: 64008-235 -Teresina, PI, Brasil. E-mail: anacathanf@hotmail.com

Conflict of interests: nothing to declare - Financial support: none. 
RESUMO: Introdução: A imunização é ação prioritária do Ministério da Saúde por contribuir substancialmente para a redução da mortalidade infantil. Porém, estudos mostram aumento de atrasos vacinais. Objetivo: Este estudo objetiva analisar a situação vacinal de crianças pré-escolares em Teresina - PI. Métodos: Trata-se de um estudo seccional envolvendo 542 crianças de 2 a 6 anos, matriculadas na rede pública municipal de ensino em quatro Centros de Educação Infantil, escolhidos aleatoriamente, obedecendo a divisão proporcional por regiões da cidade. Procedeu-se com entrevista, utilizando-se formulário pré-codificado e pré-testado, além da digitalização da caderneta de vacina. Para análise estatística descritiva univariada, aplicou-se o Teste do $\chi^{2}$ de Pearson e Teste Exato de Fisher e, para análise múltipla, procedeu-se com regressão logística múltipla, utilizando o aplicativo SPSS versão 17.0. O estudo obedeceu aos aspectos éticos, em conformidade com a legislação vigente. Resultados: A taxa de atraso vacinal/não vacinação foi de $24,9 \%$. A média de vacinas não administradas foi de $1,7( \pm 1,2)$ e a de vacinas atrasadas foi de 3,3 ( $\pm 1,6)$. O modelo de regressão logística revelou associação significativa $(\mathrm{p}<0,05)$ entre cuidadores jovens (até 24 anos) e baixa frequência em consulta de puericultura com atraso vacinal/não vacinação. Não houve associação com as variáveis relacionadas à vivência das crianças na sala de vacina e com a atuação da Estratégia de Saúde da Família. Conclusão: A garantia e fortalecimento das ações de atenção básica são ferramentas imprescindíveis para reduzir atrasos e não vacinação. Os profissionais das salas de vacina precisam estar sensibilizados a fim de orientar e estimular os pais/cuidadores a cumprirem os esquemas vacinais sem atrasos ou equívocos.

Palavras-chave: Imunização. Cobertura vacinal. Saúde da Criança. Enfermagem. Enfermagem em Saúde Comunitária. Epidemiologia.

\section{INTRODUCTION}

Concerns about child's health have been guiding public health policies particularly from the 1980 s, mainly to reduce infant mortality, which was showing alarming rates ${ }^{1}$. Due to the increased coverage of immunization actions, the access to safe drinking water and the integrated health services, the death of 10 million children was avoided per year in developing countries ${ }^{2}$. In Brazil, the main programs that addressed the immunization measures were the National Immunization Program (PNI), Comprehensive Assistance Program for Children's Health (PAISC) and the Family Health Strategy (ESF) ${ }^{1,3}$.

Immunization is among the best prevention strategies for infant mortality and morbidity $^{2,4}$, and its benefit-cost ratio outweighs the therapeutic actions and health rehabilitation ${ }^{5}$. It is an active process, which mainly depends on the child's caregiver initiative ${ }^{6}$. It is essential to respect the recommended immunization schedule for every age in order for the child to be considered immunized, since the delay in vaccination can be as damaging as not to vaccinate $^{5}$. Besides the fact that children unvaccinated or vaccinated late have greater chance of developing diseases, this incurs greater risk of epidemic $\mathrm{c}^{7.9}$, especially in the case of single-dose vaccines, whose non-observance leads to the total absence of protection ${ }^{5}$.

A multicenter study shows that the determinants of delays and non-vaccination in a community vary by location, socio-economic status, among others. The higher is the social stratification, the greater is the difficulty in standardizing these factors that contribute to 
delays in the vaccination of children. In poorer regions, there are various interrelated factors as cultural and educational barriers and structural health services problems that hinder adherence to vaccination'.

The National Immunization Program (PNI) monitors vaccination coverage, since it subsidizes the public policy making, being an excellent indicator of the population's health ${ }^{10}$. However, the methodology adopted by the Ministry of Health (MS) to calculate the vaccine coverage is inappropriate as it is based in the coverage per vaccine and not in the number of immunized children. In other words, the methodology ignores the age at which the dose of vaccine was administered and the completion of the immunization schedule. Therefore, we assume that vaccination coverage is still lower than the one informed by the PNI information system, which does not yet reach the goals set by $\mathrm{PNI}^{7,11}$. According to an interview-based study in countries with different economic situations, there is a great discrepancy in the vaccination status of children and local estimates do not capture these variations ${ }^{12}$. Thus, it is essential to conduct immunization coverage surveys and to develop electronic records in order to assess this coverage in a more consistent manner.

The Family Health Strategy (ESF) facilitated access to the vaccination rooms, because it allows the PNI to expand their actions, getting closer to the communities and generating more opportunities to vaccinate ${ }^{10}$. Children who do not take advantage of the vaccination opportunities may be the same who do not attend the well-child visits in some locations ${ }^{13}$, which reinforces the importance and interdependence between the two situations ${ }^{14}$.

A study that investigated the factors associated with delayed immunization conducted in Botucatu - SP showed that larger families with a larger number of children tend to delay vaccination, due to the dissipation of per capita income ${ }^{11}$. In another study, low maternal education directly impacted children's health and immunization ${ }^{6}$. In areas where Family Health Strategy (ESF) works better with well structured primary healthcare actions, regardless of socio-economic status, there is an improvement in vaccination coverage $\mathrm{e}^{11,13}$. These findings show that these factors are unique to each location, as there are a variety of determinants for vaccine delay and non-vaccination, which deserve thorough investigation.

In the face of scientific evidence presented, this study aims at examining the vaccination status in preschool children from Teresina (PI), Brazil. We believe that vaccination coverage rates provided by PNI do not reflect the reality of the vaccination status of preschool children in Teresina, which must be uncovered and learned specially in relation to the factors that contribute to its occurrence.

\section{METHODS}

This is cross-sectional study with a sample of 542 preschool children between two and six years old, enrolled in the local public schools in Teresina (PI). The provision of early childhood education takes place in the Municipal Centers for Early Childhood Education (CMEI), responsible for the children's initiation into education. 
According to the latest 2010 census data, most children from 2 to 6 years old, enrolled in educational institutions in Teresina, are enrolled in public schools ${ }^{15}$. All selected Municipal Centers for Early Childhood Education (CMEIs) participated in previous draw, according to the proportional division by regions. The sample range was calculated with minimum of 131 and maximum of 145 children, based on the average of children by region by CMEI and the sample size of 138 children, considering $5 \%$ error.

The sample was defined by a study developed in parallel with this, entitled Excesso de peso e obesidade em pré-escolares de Teresina-PI e associação com o consumo alimentar e nível de atividade física (Overweight and obesity in preschool children from Teresina, PI and its association with diet habits and physical activity). We believe it was timely and important to analyze other aspects of this population's health, including the immunization status. Thus, it started with a prevalence of $10 \%$ of overweight and obesity in Brazilian children from low socio-economic condition ${ }^{16}$. The values $\mathrm{p}=0.10$ and $\mathrm{q}=1-\mathrm{p}=0.90$ with a margin of error (e) of $5 \%$ and $95 \%$ confidence level were considered. The sample size (n) was calculated as follows: $\mathrm{n}=\mathrm{z}^{2} \mathrm{xpq} / \mathrm{e}^{2}$, being $\mathrm{p}$ the proportion of children with obesity, $\mathrm{c}=1$ - $\mathrm{p}$ and $z=1.96$ is the score of the normal curve for the established confidence level. The value achieved was equal to 138 children, distributed in the following regions: North $=135$, South $=136$, East $=137$ and Southeast $=134$. These values are very close to the sample, so it was not necessary to use weighting factors.

In order to confirm that $n$ equivalent to 542 is indeed representative for the study, the minimum value of $n$ was calculated. The sample size calculation for the proportions estimative considered the prevalence of $50 \%$ of the dependent variable - delayed vaccine - given that there was no prior information for the studied population, with an estimated $p$ proportion of delayed immunization in the population $=50 \%=0.5$, and the estimated $q$ proportion of individuals without obesity $=50 \%=0.5$ (note that $p+q=100 \%$ ). The desired accuracy for prevalence is $=3 \%$. Thus, the standard error is half this value: $\mathrm{E}=1.5 \%=0.015$. The following formula was used to calculate sample size: $\mathrm{n}=\mathrm{pq} \div \mathrm{e}^{2}$, where $\mathrm{n}=0.5(0.5) \div$ $0,015^{2}=0.05 \div 0.000225=222$ children as minimum sample. However, we decided to constitute a sample higher than twice the minimum necessary, given that the interviewers of the research group would collect data among 542 preschoolers, enabling a larger sample for the study of delayed immunization.

The information was provided by those responsible for the care of the child. These were referred to as caregivers. Interviews with caregivers were conducted from February to July 2013 in order to fill a structured form, containing questions of a socio-demographic nature related to vaccination status, experience in the vaccination room and child's health, as well to consult and digitize the immunization card.

In this study, the delayed vaccination was computed when the scheduled dose had not been administered in the correct date then the number of days past due was calculated for further analysis and coding in delays greater or lesser than 15 days. The cases where the child had not taken the recommended vaccine until the date of the interview were classified as non-vaccination. Vaccines in single dose and multiple doses have been 
computed jointly. Other numerical variables were recoded as the age of the caregiver, in which the range was defined as "under 24 " or " 25 years or more". This age categorization was chosen due to the fact that only $4.2 \%$ of the caregivers had between 15 and 19 years old, which would result in not feasible statistical tests due to the generation of tiers with zero value.

In order to conduct the statistical analysis, a database was built in the Epi Info version $6.04 \mathrm{~d}$ application, with inputs in two different files for errors correction. Later, the data were exported to the Statistical Package for Social Sciences - SPSS, version 17.0 for testing. In the bivariate analysis we used the $\chi^{2}$ test of Pearson or Fisher's exact test, as needed, considering a $95 \%$ confidence interval and error of $5 \%$, which provided potential predictors for delayed immunization status in children. The combined effect of the independent variables on the delayed vaccination was obtained by multiple logistic regression, being qualified variables with $\mathrm{p}<0.20$ in the bivariate analysis ${ }^{17}$.

The study was authorized by the City Department of Education and Culture (SEMEC) Teresina (PI). The project was also examined and approved by the Ethics Committee of the Universidade Federal do Piauí. The research was self-funded and authors share the same interests.

\section{RESULTS}

The results revealed the profile of the subjects regarding socio-demographic aspects, which most were: children aged four to six years (57.7\%); child's own mother was the caregiver (82.8\%); children were most female (51.1\%); lived in brick houses $(90.6 \%)$; caregivers were married or in a common-law marriage (66.6\%), having at most incomplete secondary education $(61.3 \%)$; per capita income equivalent to a maximum of one quarter of the national minimum wage $(66.8 \%)$; (Table 1$)$.

Among the information obtained not shown in Table 1, the following were also observed in the majority of the cases: caregivers were adults (94.6\%); caregiver spouse was the main financial provider (51.5\%); income source from formal employment (49.7\%); family size of up to five members $(77.3 \%)$ with an average of $4.7( \pm 2.0)$.

The vaccination status of children is presented in Table 2 . The rate of delayed vaccination or non-vaccination was $24.9 \%$. The delayed vaccination greater than 15 days totaled $85.2 \%$ of those who computed delayed immunization. The average of non-administered vaccines, not shown in table 2 , was $1.7( \pm 1.2)$, and the average of delayed vaccines was 3.3 ( \pm 1.6$)$. The most common reasons mentioned by parents for the delayed vaccination were: the lack of vaccine in the public health units $(36.4 \%)$, caregiver negligence $(24.4 \%)$ and child illness $(20 \%)$. Among the reasons included in the category Others, not shown in Table 2, the most common was limited time availability of the caregivers $(8.9 \%$ of those who delayed vaccinations) and distance from the public health unit $(2.2 \%$ of those who delayed vaccinations). 
Table 1. Delayed vaccination distribution in children aged 2 to 6 years according to demographic characteristics. Teresina (PI), 2013.

\section{Variables}

$\mathrm{n}$

$\%$

Caregiver age (years)

Up to 24

$25+$

\begin{tabular}{l|l}
\hline 127 & 23.4 \\
\hline 415 & 76.6
\end{tabular}

Children age (full years)

2 to 3

4 to 6

\begin{tabular}{|l|r|}
\hline 229 & 42.3 \\
\hline 313 & 57.7
\end{tabular}

Children's degree of relation

\begin{tabular}{|l|c|c|}
\hline Mother & 449 & 82.8 \\
\hline Father & 35 & 6.5 \\
\hline Grandmother/Grandfather & 42 & 7.8 \\
\hline Aunt / Uncle & 10 & 1.8 \\
\hline Others & 6 & 1.1 \\
\hline
\end{tabular}

Children's gender

\begin{tabular}{|l|l|l}
\hline Male & 265 & 48.9 \\
\hline Female & 277 & 51.1
\end{tabular}

Origin

North Zone

East Zone

Southeast Zone

South Zone

\begin{tabular}{|l|l|}
\hline 135 & 24.9 \\
\hline 137 & 25.2 \\
\hline 135 & 24.9 \\
\hline 136 & 25.0 \\
\hline
\end{tabular}

Type of House

Brick

Others

Caregiver marital status

\begin{tabular}{l|c|c} 
Single & 134 & 24.7 \\
\hline Married/ Common-law marriage & 361 & 66.6 \\
\hline Divorced & 40 & 7.4 \\
\hline Widowed & 7 & 1.3
\end{tabular}

Caregiver Educational Level

Up to completed Elementary School Incomplete High School and higher

\begin{tabular}{|c|r|}
\hline 491 & 90.6 \\
\hline 51 & 9.4
\end{tabular}

Main family financial provider

\begin{tabular}{|l|l|l|}
\hline Caregiver and/or Spouse & 426 & 78.6 \\
\hline Other people & 116 & 21.4 \\
\hline
\end{tabular}

Per capita Income

\begin{tabular}{l|c|c}
\hline$<0.25$ Minimum Wage & 362 & 66.8 \\
\hline$\geq 0.25$ Minimum Wage & 180 & 33.2
\end{tabular}


Table 2. Data on delayed vaccination/non-vaccination and vaccination room visits of children aged 2 to 6 years. Teresina (PI), 2013.

\section{Variables}

$\mathrm{n}$

$\%$

Delayed vaccination occurred

\begin{tabular}{|c|c|r} 
Yes & 135 & 24.9 \\
\hline No & 407 & 75.1
\end{tabular}

Length of vaccination delay

Up to 15 days

More than 15 days

\begin{tabular}{|c|r|}
\hline 20 & 14.8 \\
\hline 115 & 85.2 \\
\hline
\end{tabular}

Number of delayed vaccination

Up to 3 vaccines

More than 3 vaccines

\begin{tabular}{|l|r|}
\hline 76 & 58.0 \\
\hline 55 & 42.0
\end{tabular}

Number of non-administered doses

$$
\text { Up to } 3 \text { vaccines }
$$

More than 3 vaccines

\begin{tabular}{|c|c|}
\hline 53 & 93.0 \\
\hline 4 & 7.0 \\
\hline
\end{tabular}

Reasons for delayed vaccination

Lack of vaccines in the public health unit

Neglect

Child was sick

Others

\begin{tabular}{|l|l|}
\hline 49 & 36.4 \\
\hline 33 & 24.4 \\
\hline 27 & 20.0 \\
\hline 26 & 19.2 \\
\hline
\end{tabular}

Disease that motivated delayed vaccination

\section{Respiratory Infection \\ Extreme prematurity \\ Others}

Reactions to a vaccine*

\begin{tabular}{|l|l|l} 
Yes & 114 & 21.5 \\
\hline No & 417 & 78.5
\end{tabular}

Difficulties in taking the child to the public health unit

\begin{tabular}{|c|c|c} 
Yes & 43 & 7.9 \\
\hline No & 499 & 92.1 \\
\hline
\end{tabular}

Received guidance in relation to the vaccine in the health unit

\begin{tabular}{|c|c|r} 
Yes & 365 & 67.3 \\
\hline No & 177 & 32.7 \\
\hline
\end{tabular}

Type of guidance received

More than one of the above guidance

How to deal with the reactions to vaccine

Scheduling of next vaccine

Clarified the importance of the vaccine

Others

\begin{tabular}{|c|c|c}
\hline & 140 & 38.4 \\
\hline & 136 & 37.3 \\
\hline & 33 & 9.0 \\
\hline & 52 & 14.2 \\
\hline
\end{tabular}

* 11 cases, in which there was no available information about the vaccine reactions, were excluded. 
With regard to vaccine reactions, one in five children had reactions after receiving any dose of vaccine. It was observed that a significant portion of the caregivers received guidance during visits to public vaccination units $(67.3 \%)$ (Table 2$)$.

The performance of the Family Health Strategy (ESF), from the perspective of the caregivers, is further described in Table 3. The ESF health professionals' visits occurred in $63.7 \%$ of the cases studied. The average of home visits performed by the community health agent was 8.8 ( \pm 5.1 ) per year and the majority of the respondents mentioned to be visited at least once a month $(62 \%)$. During these visits, the community health agent questioned the vaccine status in $76.2 \%$ of the households, and among these, the child's vaccination card was examined in $51.3 \%$ of the cases.

The association between vaccination delay and the variables related to children's health occurred in the variable "frequency of the child in the well-child visits", with $p<0.001$, indicating strong association with vaccination delay in the univariate analysis (Table 4).

Table 5 shows a statistically significant association between the delayed vaccination and the age of caregivers, as well as the frequency of well-child visits. Teenagers and young caregivers were $61 \%$ more likely to delay vaccinating their children than caregivers aged over 24 years. Those children whose caregivers do not take them to well-child visits were $71 \%$ more likely to delay the vaccine compared to those who attend regularly.

Table 3. Performance of the Family Health Strategy in the homes of children aged 2 to 6 years. Teresina (PI), 2013.

\begin{tabular}{|c|c|c|}
\hline Variables & $\mathrm{n}$ & $\%$ \\
\hline \multicolumn{3}{|c|}{ Home visits from Family Health Strategy (ESF) professionals occurred } \\
\hline Yes & 345 & 63.7 \\
\hline No & 197 & 36.3 \\
\hline \multicolumn{3}{|l|}{ Frequency of the ESF Health Agent home visits } \\
\hline One or more visits per month & 214 & 62.0 \\
\hline Less than one visit per month & 131 & 38.0 \\
\hline \multicolumn{3}{|l|}{ ESF Health Agent approach to vaccination } \\
\hline Yes & 263 & 76.2 \\
\hline No & 82 & 23.8 \\
\hline \multicolumn{3}{|c|}{ Type of approach of the ESF Health Agent to vaccination } \\
\hline Verified the children's vaccination card & 135 & 51.3 \\
\hline More than one alternative & 106 & 40.3 \\
\hline Explained about the importance of the vaccine & 11 & 4.2 \\
\hline Referred to the vaccination unit & 4 & 1.5 \\
\hline Others & 7 & 2.7 \\
\hline \multicolumn{3}{|l|}{ Visits from other ESF Health professionals } \\
\hline Doctor & 26 & 50.1 \\
\hline Nurse & 17 & 33.3 \\
\hline Dentist & 5 & 9.8 \\
\hline More than one professional & 3 & 5.8 \\
\hline
\end{tabular}


Table 4. Data on birth and health of children aged 2 to 6 years, according to delayed immunization. Teresina (PI), 2013.

\begin{tabular}{|c|c|c|c|c|c|}
\hline \multirow{2}{*}{ Variables } & \multirow{2}{*}{$\mathrm{n}$} & \multirow{2}{*}{$\%$} & \multicolumn{2}{|c|}{ Delayed Vaccination } & \multirow{2}{*}{$\mathrm{p}$-value } \\
\hline & & & Yes (\%) & No $(\%)$ & \\
\hline \multicolumn{6}{|c|}{ Received exclusive breastfeeding } \\
\hline Yes & 379 & 70.4 & 24.5 & 75.5 & \multirow{2}{*}{$0.647^{*}$} \\
\hline No & 159 & 29.6 & 26.4 & 73.6 & \\
\hline \multicolumn{6}{|l|}{ Gestational age } \\
\hline Term pregnancy & 498 & 91.9 & 24.1 & 75.9 & \multirow{2}{*}{$0.142^{*}$} \\
\hline Preterm pregnancy & 44 & 8.1 & 34.1 & 65.9 & \\
\hline \multicolumn{6}{|l|}{ Low birth weight } \\
\hline Yes & 130 & 24.0 & 25.4 & 74.6 & \multirow{2}{*}{$0.885^{*}$} \\
\hline No & 412 & 76.0 & 24.8 & 75.2 & \\
\hline \multicolumn{6}{|c|}{ Frequency of well-child visits } \\
\hline Regularly & 336 & 62.0 & 22.9 & 77.1 & \multirow{3}{*}{$0.000^{*}$} \\
\hline Do not attend & 31 & 5.7 & 54.8 & 45.2 & \\
\hline Occasionally & 175 & 32.3 & 23.4 & 76.6 & \\
\hline
\end{tabular}

Table 5. Binomial logistic regression model for the influence of characteristics of children on immunization delays. Teresina (PI), 2013.

\begin{tabular}{|c|c|c|}
\hline Variables & ORa $(95 \% \mathrm{Cl})$ & p-value \\
\hline \multicolumn{3}{|l|}{ Caregiver Age } \\
\hline Up to 24 years old & $1.61(1.19-1.86)$ & \multirow{2}{*}{0.043} \\
\hline $25+$ years old & 1 & \\
\hline \multicolumn{3}{|l|}{ Child's gender } \\
\hline Male & $0.75(0.33-1.06)$ & \multirow{2}{*}{0.171} \\
\hline Female & 1 & \\
\hline \multicolumn{3}{|l|}{ Per capita Income } \\
\hline$<0.25$ Minimum wage & $1.34(0.88-1.97)$ & \multirow{2}{*}{0.118} \\
\hline$\geq 0.25$ Minimum wage & 1 & \\
\hline \multicolumn{3}{|c|}{ Difficulties in taking the child to vaccination units } \\
\hline Yes & $1.74(0.92-2.14)$ & \multirow{2}{*}{0.115} \\
\hline No & 1 & \\
\hline \multicolumn{3}{|l|}{ Gestational Age } \\
\hline Term pregnancy & $0.64(0.27-1.04)$ & \multirow{2}{*}{0.203} \\
\hline Preterm pregnancy & 1 & \\
\hline \multicolumn{3}{|c|}{ Frequency of well-child visits } \\
\hline Regularly & 1 & \multirow{3}{*}{0.002} \\
\hline Do not attend & $1.71(1.32-2.11)$ & \\
\hline Occasionally & $1.03(1.01-1.06)$ & \\
\hline
\end{tabular}

ORa: Adjusted odds ratio; 95\% Cl: confidence interval of 95\%; P: significance of the logistic regression model; HosmerLemeshow Test $=0.942$. 


\section{DISCUSSION}

\section{CHARACTERIZATION OF CHILDREN WITH REGARD TO SOCIO-DEMOGRAPHIC ASPECTS ASSOCIATED WITH DELAYED IMMUNIZATION}

In this study, the socio-demographic variable that was associated with the delayed vaccination in both bivariate and multivariate analysis was restricted to the age of the caregiver.

The literature argues that the young / teenage mother is able to care for her child, with no differences compared to an adult mother ${ }^{18}$. Parents usually have family's comprehension, acceptance and support in facing a pregnancy, desired or not, being the grandmother involved in child's care, assuming sometimes the full responsibility ${ }^{19}$. However, young parents understand that they have not matured enough yet to take responsibility for the child's health ${ }^{20}$. Therefore, motherhood, if idealized as personal fulfillment, enhances the acceptance of immunization, whereas the youth inexperience contributes to non-vaccination ${ }^{14}$.

With regard to socio-demographic data, per capita income showed no association with vaccination delay. This reflects the recent trend of increasing coverage among the poorest layers, especially when they are better assisted by preventive health services ${ }^{21}$. This trend is pointed out by another study conducted in Teresina - PI, which attributes this result to the enhancement of primary health care, especially from the Family Health Strategy (ESF), which worked in micro-regions and attended priority health problems in such communities ${ }^{21}$. On the other hand, in Botucatu - SP, a study showed tendency towards delayed vaccination in large families especially when there is a larger number of children, due to the dissipation of per capita income ${ }^{11}$.

However, a study conducted in the UK showed that people who attend the private network of health care, with higher levels of education, have considerable chances of non-vaccination and refusal to vaccinate their children. The reasons are self-sufficiency in relation to family health and low confidence in the effects of mass vaccination ${ }^{22}$. In this sense, dialogue and elucidation are critically important to restore confidence in vaccination as well as to understand the magnitude of these refusals in community immunity ${ }^{9}$.

In New Zealand, the contribution of socio-demographic factors is less than $1 \%$, while in some ethnic groups in the UK, it can reach $80 \%{ }^{23}$. Other administrative factors related to the planning of basic health units and immunobiological distribution network contributed to delayed vacination ${ }^{22}$.

\section{ANALYSIS OF VACCINATION STATUS AND EXPERIENCE IN CHILDREN'S VACCINATION ROOM}

One in four children in this study had delayed immunization when computing doses administered with delay and not administered, which may be considered alarming compared to the National Immunization Program (PNI) targets, ranging from 90 to $95 \%$ coverage of all basic vaccination schedule ${ }^{11}$. 
Among the reasons expressed by parents for vaccine delays and / or non-vaccination, the most frequent were the lack of vaccines and neglect. Vaccine losses are possibly due to the expiration date, broken vials and problems in the cooling network, as the improper handling, equipment malfunctioning, or the lack of electricity, which interrupts the cooling process, compromising the vaccine effectiveness ${ }^{11}$.

According to the literature, it was observed that the higher the number of doses that the vaccine has in the vaccination schedule, the greater are the chances of delayed vaccination ${ }^{24}$. It is assumed that the person responsible for the child considers these subsequent doses less important and therefore unnecessary. Vaccines in single dose hardly fail to be administered ${ }^{24}$.

Adverse events were not investigated using the National Immunization Program (PNI) protocols for diagnosing and differentiating the expected and the adverse events after vaccination, by virtue of the inquiry to the mother about the reactions to vaccine. This leads to a limitation in the study; however, it does not become impracticable nor prevents the use of the variable, considering that this was not the central aspect of the survey.

\section{ASPECTS RELATED TO THE PERFORMANCE OF THE FAMILY HEALTH STRATEGY (ESF) AND THE HEALTH OF CHILDREN WHO CONTRIBUTED TO THE DELAYED IMMUNIZATION}

The Family Health Strategy (ESF) has a key role for contributing to increase vaccination coverage $^{25}$ and to reduce infant mortality ${ }^{26}$, however, the deficit in its execution is well known ${ }^{11,27}$.

Many teams operate with deficiencies, both structural and those related to the activities developed by the professionals ${ }^{28}$. The lack of guidance given to parents during visits to the vaccination unit detected in this study is an unacceptable finding for a service that strive for health promotion, whose foundation is the health education.

In Family Health Strategy (ESF), activities such as home visits are decisive in the creation of the link between professionals and families. An intervention study in the USA showed that in regions where there is a higher frequency of home visits, there is better monitoring of children and less chance of failure in the vaccination process ${ }^{13}$. Regarding the monitoring of children's health, the aspect that requires more attention for contributing to the vaccine delay was the frequency of well-child visits. The minimum visits frequency corresponds to an annual consultation in primary health care provided by Single Health System (SUS $)^{1}$.

Both health professionals and parents / guardian focused attention in the deterioration of conditions of the children's health, neglecting the primary care and periodic monitoring $^{29}$. The professionals attributed this situation to work overload, to inexperience and lack of resources in order to justify failure to check children's vaccination cards during visits ${ }^{30,31}$. Parents / caregivers who do not take their children to routine consultations at Public Health Units or take them only occasionally are strong candidates to neglect children's vaccination. During well-child visits, the nurse of the Family Health Strategy (ESF) should educate parents about immunization of children, either verifying the current knowledge and / or referring them to the vaccination room to ensure that the vaccination schedule is followed ${ }^{32}$. 
Although the law guarantees vaccination and, above all, the right to access healthcare services, there are still health professional teams that do not develop actions related to primary care ${ }^{30}$. When the well-child checkup occurs, it reveals deficiencies such as the focus only on the disease, lack of sufficient staff who can adequately attend all families, among others problems ${ }^{30}$.

\section{CONCLUSION}

This study revealed that there is significant delayed vaccination among children. Delayed vaccination can trigger serious problems in a short period of time if it remains unnoticed. Knowing that children who do not attend well-child visits are more likely to delay their vaccines elucidates perhaps the largest, best and simplest alternative: guaranteeing and enhancing primary health care actions.

Similarly, to sensitize the professionals who attend children in the vaccine rooms encourages parents / caregivers in following the vaccination schedules without delays or misunderstandings. The community needs more support, comfort and attention to their difficulties than procedures and well-executed activities ${ }^{24}$.

Despite the important findings of this study that will subsidize the management and policies related to children's health, there are some limitations that do not invalidate the study, but should be avoided in future studies. One limitation is that the participant population involved only children in the public school system and who lived in the urban area, making it impossible to infer the same results for children from families with higher income and for the whole children population in the areas represented in this study. Moreover, further studies should explore aspects involving structural and organizational factors impacting the achievement of desired vaccine coverage.

\section{REFERENCES}

1. Brasil. Ministério da Saúde. Secretaria de Atenção à Saúde. Departamento de Atenção Básica. Saúde da criança: crescimento e desenvolvimento. Brasília: Ministério da Saúde; 2012. (Cadernos de Atenção Básica, n 33).

2. World Health Organization (WHO), United Nations International Children's Emergency Fund (UNICEF), World Bank. State of the world's vaccines and immunizations. $3^{\text {rd }}$ ed. Geneva: WHO; 2009.

3. Brasil. Ministério da Saúde. DATASUS. Sistema de Informação de Mortalidade - SIM, 2010. Disponível em: http: / / tabnet.datasus.gov.br (Acessado em 13 de dezembro de 2013).
4. United Nations International Children's Emergency Fund (UNICEF). Situação Mundial da Infância 2013: crianças com deficiência. Disponível em: http: / / www. unicef.org/brazil/pt/resources_25542.htm (Acessado em 15 de janeiro de 2014).

5. Joyce C. Steps to success: getting children vaccinated on time. Pediatr Nurs 2007; 33(6): 491-6.

6. Lima CRV, Bispo BKS, Araujo EAN, Monteiro EMLM, Low ST. Dificuldades relatadas pelos pais/responsáveis para o cumprimento da imunização básica das crianças de uma creche. Rev Enferm UFPE on line 2012; 6(10): 2404-10 
7. Mello MRL, Mores JC, Barbosa HA, Flannery B. Participação em dias nacionais de vacinação contra poliomielite: resultados de inquérito de cobertura vacinal em crianças nas 27 capitais brasileiras. Rev Bras Epidemiol 2010; 13(2): 278-88.

8. Pugliesi MV, Tura LFR, Andreazzi MFS. Mães e vacinação das crianças: estudo de representações sociais em serviço público de saúde. Rev Bras Saude Mater Infant Mar 2010; 10(1): 75-84.

9. Glatman-Freedman A, Nichols KA. The effect of social determinants on immunization programs. Hum Vaccin Immunother 2012; 8(3): 293-301.

10. Brasil. Ministério da Saúde. Fundação Nacional da Saúde. Manual de Procedimentos para Vacinação. $4^{\mathrm{a}}$ ed. Brasília: Ministério da Saúde; 2001.

11. Molina AC, Godoy I, Carvalho LR, Caldas Júnior AL. Situação vacinal infantil e características individuais e familiares do interior de São Paulo. Acta Sci. Health Sci 2007; 29(2): 99-106.

12. Clark A, Sanderson C. Timing of children's vaccinations in 45 low-income and middle-income countries: an analysis of survey data. Lancet 2009; 373(9674): 1543-9.

13. Hambidge SJ, Phibbs SL, Chandramouli V, Fairclough D, Steiner JF. A Stepped Intervention Increases WellChild Care and Immunization Rates in a Disadvantaged Population. Pediatrics 2009; 124(2): 455-64.

14. Figueiredo GLA, Pina JC, Tonete VLP, Lima RAG, Mello DF. Experiências de famílias na imunização de crianças brasileiras menores de dois anos. Rev Latino-Am Enfermagem 2011; 19(3): 598-605.

15. Instituto Brasileiro de Geografia e Estatística (IBGE). Censo Demográfico de 2010: Resultado da Amostra Educação. Disponível em: http: / / www.cidades.ibge. gov.br $/$ xtras $/$ temas.php?lang $=\&$ codmun $=221100 \& i d t$ ema $=105 \&$ search $=$ piaui $\mid$ teresina $\mid$ censo-demografico2010:-resultados-da-amostra-educacao-- (Acesso em 15 de janeiro de 2014).

16. Silva GAP, Balaban G, Motta MEF. Prevalência de sobrepeso e obesidade em crianças e adolescentes de diferentes condições socioeconômicas. Rev Bras Saúde Matern Infant 2005; 5 (1): 53-59.

17. Hosmer DW, Lemeshow S. Applied logistic regression. $2^{\text {nd }}$ ed. New York: John Wiley \& Sons; 2000.

18. Vieira MLF, Bicalho GG, Silva JLCP, Barros Filho AA. Crescimento e desenvolvimento de filhos de mães adolescentes no primeiro ano de vida. Rev Paul Pediatr 2007; 25(4): 343-8.

19. Dias AB, Aquino EML. Maternidade e paternidade na adolescência: algumas constatações em três cidades do Brasil. Cad Saúde Pública 2006; 22(7): 1447-58.

20. Castro MG, Abramovay M, Silva LB. Juventude e sexualidade. Brasília: UNESCO Brasil; 2004.
21. Luhm KR, Cardoso MRA, Waldman EA. Cobertura vacinal em menores de dois anos a partir de registro informatizado de imunização em Curitiba, PR. Rev Saúde Pública 2011; 45(1): 90-8.

22. Araújo TME. Vacinação infantil: conhecimentos atitudes e práticas da população da área norte/centro de Teresina/PI [Tese de Doutorado]. Rio de Janeiro: Escola de Enfermagem Anna Nery, Universidade Federal do Rio de Janeiro; 2005.

23. Palmer S, McNeill R. Socio-demographic variables and parental decision-making about childhood vaccines-is education more important than deprivation? Disponível em: http: / / tumana.maori.nz/assets/Uploads/other/ Sociodemographic\%20variables\%20and\%20vax\%20 status.doc (Acessado em 15 de junho de 2014).

24. Tertuliano GC, Stein AT. Atraso vacinal e seus determinantes: um estudo em localidade atendida pela Estratégia Saúde da Família. Ciênc Saúde Coletiva 2011; 16(2): 523-30.

25. Silva TASM, Carreiro MA. Diagnóstico situacional do preparo e administração de imunobiológicos. Rev Enferm UERJ 2012; 20(4): 451-6.

26. Guimarães TMR, Alves JGB, Tavares MMF. Impacto das ações de imunização pelo Programa Saúde da Família na mortalidade infantil por doenças evitáveis em Olinda, Pernambuco, Brasil. Cad Saúde Pública 2009; 25(4): 868-76.

27. Carvalho AMC, Araujo TME. Fatores associados à cobertura vacinal em adolescentes. Acta Paul Enferm 2010; 23(6): 796-802.

28. Paiva TSC. A situação vacinal das crianças que apresentaram eventos adversos com vacina tetravalente no município de Belém-PA [Dissertação de Mestrado]. Belém: Universidade Estadual do Pará; 2008.

29. Vasconcelos VM, Frota MA, Martins MC, Machado MMT. Puericultura em enfermagem e educação em saúde: percepção de mães na estratégia saúde da família. Esc Anna Nery 2012; 16(2); 326-31.

30. Assis WD, Collet N, Reichert APS, Sá LD. Processo de trabalho da enfermeira que atua em puericultura nas unidades de saúde da família. Rev Bras Enferm 2011; 64(1): 38-46.

31. Campos RMC, Ribeiro CA, Silva CV, Saparolli ECL. Consulta de enfermagem em puericultura: a vivência do enfermeiro na Estratégia de Saúde da Família. Rev Esc Enferm USP 2011; 45(3): 566-74.

32. Saparolli ECL, Adami NP. Avaliação da qualidade da consulta de enfermagem à criança no Programa de Saúde da Família. Acta Paul Enferm 2007; 20(1): 55-61.

Received on: 08/20/2014

Final version presented on: 01/19/2015

Accepted on: 05/05/2015 